\title{
Effects of Varieties and Intra Row Spacing on Yield of Maize (Zea mays L.) under Supplementary Irrigation at Guliso, Western Ethiopia
}

\author{
Tasisa Temesgen* and Teshome Kebena \\ School of Natural Resource Management and Environmental Sciences, Haramaya University, Ethiopia
}

Submission: March 20, 2019; Published: June 04, 2019

*Corresponding author: Tasisa Temesgen, School of Natural Resource Management and Environmental Sciences, Haramaya University, Ethiopia

\begin{abstract}
Determination of optimum plant population and the use of improved varieties in combination with appropriate agronomic practices are important components of maize production package for maximizing productivity. The study was conducted 2017-2018 under supplementary irrigation at Gulliso district, Western Ethiopia, to determining the effects of variety and intra-row spacing on yield of maize (Zea mays L.). The experiment was conducted in factorial arrangement of four intra-row spacing $(20,25,30$ and $35 \mathrm{~cm})$ with three maize varieties (BH546, Shone and BHQPY-545) in RCBD. The interaction of variety and intra-row spacing was highly significant $(\mathrm{P}<0.01)$ on yield components and yield of maize. The highest (1.75) average number of ears per plant was recorded from varieties BH546 and BHQPY-545 at $35 \mathrm{~cm}$ intra-row spacing. The highest $(35 \mathrm{~cm})$ ear length was recorded from BH546 at $35 \mathrm{~cm}$ intra-row spacing. Generally, leaf area, stand count, ears per plant, ear length, and ear diameter showed a decreasing trend with decreasing intra-row spacing. Based on these results, it can be tentatively concluded that the variety BH546 could be used at plant density of 53,333 plants ha ${ }^{-1}$ and $(25 \mathrm{~cm})$ intra-row spacing is best to get the highest green cob yield of maize under supplemental irrigation during the off-season in the study area.
\end{abstract}

Keywords: Intra-row Spacing; Supplementary irrigation; Plant density; Variety

\section{Introduction}

Maize (Zea mays L.) is the most widely grown cereal crop. It ranks third after wheat and rice in hectare and total production. It is predicted that by 2020 , it will surpass both wheat and rice to become the number one cereal in the world Maize demand is projected to increase by $50 \%$ worldwide and by $93 \%$ in subSaharan Africa between 1995 and 2020 (FAO, 2015).

Among cultural practices, which affect the yield, intra-row spacing is a one factor since it is ultimately related with plant density, root development, plant growth and fruiting [1]. In most cases the optimum spacing is one, which enables the plants to make the best use of conditions at their disposal [2]. Too close spacing interferes with normal plants development and increase competition resulting in yield reduction, while too wide spacing may result in excessive vegetative growth of plant and abundant weed population due to more feeding area available. Therefore, use of optimum plant population per unit area without exceeding the economic threshold can increase the competitive ability of the plants in weed-infested field [3]. In addition to improving crop yields, reduced row spacing can also provide the crop with a competitive advantage over weeds.
Andrade et al. [4] reported that spacing of $75 \mathrm{~cm} \times 35 \mathrm{~cm}$ resulted in increased grain yield of maize, while $75 \mathrm{~cm} \times 15 \mathrm{~cm}$ gave maximum cob. In the both the hybrid and the local maize, plant spacing of $25 \mathrm{~cm} \times 75 \mathrm{~cm}$ had the highest grain yield with 66,667 plants $\mathrm{ha}^{-1}$, followed by plant spacing of $30 \mathrm{~cm} \times 65 \mathrm{~cm}$ that had 50,949 plants ha- ${ }^{-1}$, while plant spacing of $100 \mathrm{~cm} \times 10 \mathrm{~cm}$ had the least grain yield [5].

In Ethiopia, the national spacing recommendation for maize is $75 \mathrm{~cm} \times 30 \mathrm{~cm}(44,444$ plants $/$ ha). This spacing has been used, without considering the numerous factors such as the existences of soil and climatic differences. In the study area, the production of maize under irrigation takes on a special significance; because there is high demand for green fresh consumption during off season if water is available for irrigation and production during the off season. For this reason, farmers produce maize under irrigation with varied plant spacing and as a result, plant population per hectare varies among farmers due to miss using proper spacing. Some of the farmers say that the national recommended spacing is too wide that it does not give higher yield. Moreover, they think as use of higher plant population may result in more yields that was visually observed. 
Thus, effects of different spacing on maize must be investigated for practical purposes, as planting spacing is a major management variable used in matching crop requirements to the environmental offer of resources. This study was addressed this problem with the objective: assess the effects of variety and intra- row spacing on growth, yield components and green cob yield of maize.

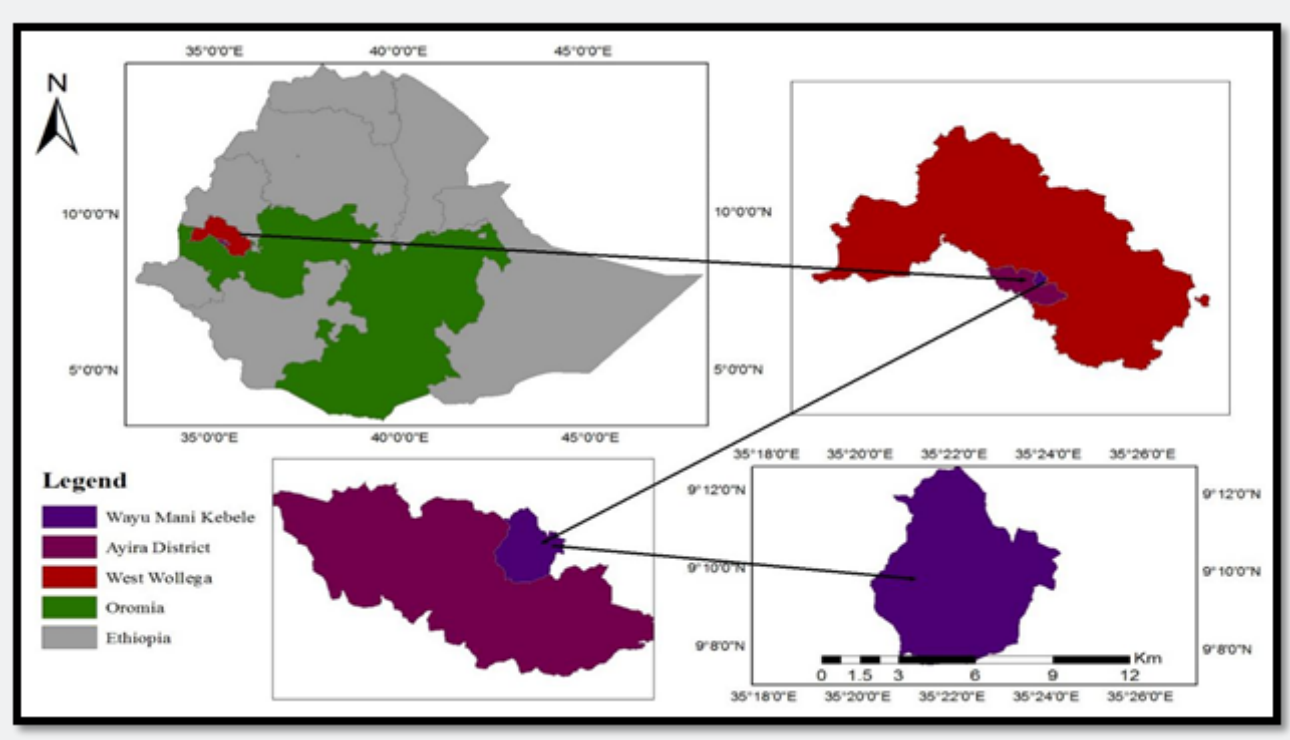

Figure 1: Map of the study area.

Materials and Method

\section{Description of the study area}

The study was conducted at Guliso District, Western Ethiopia located about at $512 \mathrm{~km}$ North West of Addis Ababa (Figure 1). The experimental site is situated at 9o 10' $00^{\prime \prime} \mathrm{N}^{\prime}$ latitude and 35022' 00" E longitude at 1538 meters above sea level. The experiment was conducted under supplementary irrigation during 2017/2018 cropping season. The rainy season starts in May and extends up to October. Meteorological data taken from Aira station, which is at about $12 \mathrm{~km}$ away from experimental site, showed annual (May-beginning of November) rain fall of $1460.9 \mathrm{~mm}$, and the mean maximum and minimum air temperature of $27 \mathrm{oC}$ and $14.94 \mathrm{oC}$ respectively.

\section{Description of experimental materials}

Three hybrid maize varieties, (BH546 and BHQPY-545 which were used for the study were released by Bako Agricultural Research Center and variety Shone (30G19) that was released by Pioneer hybrid) were used as experimental material. The yield potentials of BH546 and BHQPY 545 on research center were 8.5-11.5ton ha $^{-1}$ and 8-9ton ha ${ }^{-1}$ respectively, while on farmers field their yield potential were 6.5-7.5ton $\mathrm{ha}^{-1}$ and 5-6ton ha-1 respectively [6]. The variety Shone yield potential was 7-11ton ha $^{-1}$ and 6.5-8.5ton ha ${ }^{-1}$ on research center and farmer field respectively [7] (Table 1).

\section{Treatments and experimental design}

The treatment consists of factorial combination of 4 intrarow spacing $(20,25,30$ and $35 \mathrm{~cm})$ and three varieties of maize
(BH546, Shone (30G90) and BHQPY-545. The recommended inter row spacing of $75 \mathrm{~cm}$ for maize was used uniformly. The experiments were laid out in randomized complete block design (RCBD) in $4 \times 3$ factorial arrangements with three replications. The space between plot and block was $0.5 \mathrm{~m}$ and $1 \mathrm{~m}$ respectively. The gross plot consists of 4 rows, each $3 \mathrm{~m}$ long. The net plots were the middle 2 rows; the 2 outer rows of each plot were used as border rows. Thus, the size of the gross and net plot was $9 \mathrm{~m} 2(3 \mathrm{~m} \times 3 \mathrm{~m})$ and $4.5 \mathrm{~m} 2(3 \times 1.5 \mathrm{~m})$.Thus, the plant population corresponding to the $20 \mathrm{~cm} \times 75 \mathrm{~cm}, 25 \mathrm{~cm} \times 75 \mathrm{~cm}, 30 \mathrm{~cm} \times 75 \mathrm{~cm}$ and $35 \mathrm{~cm} \times 75 \mathrm{~cm}$ intra-inter row spacing were $66,666,53333$, 44444 and 38095 plants per hectare.

\section{Irrigation management}

For the1st month field was shallow irrigated at 7 interval days, while after a month till to tasseling and silking irrigation 10 to 12 days interval applied deeply by furrow system. And at critical time at tasseling and silking stage field was irrigated by 4 days interval to initiate flowering and silking. Most of the time irrigation has been done after noon to avoid loses of water from the field by evaporation.

\section{Data collection and measurement}

Phenological and growth parameters of maize: Days to $50 \%$ anthesis, Days to 50\% silking, Leaf area, Leaf area index (LAI), Plant height $(\mathrm{cm})$ and Plant height $(\mathrm{cm})$ were measured.

Yield and yield component: Number of ears per plant, Ear height (cm), Number of kernels per ear, hundred kernels weight (g), Grain yield $\left(\mathrm{kg} \cdot \mathrm{ha}^{-1}\right)$ and Harvest index were collected at the time of data collection. 


\section{Statistical data analysis}

The measurement variables were analyzed using the statistical analysis system (SAS) as per the RCBD factorial model. Mean separation was conducted using LSD at 5\% level of significance.

\section{Results and Discussion}

\section{Phenological parameters of Maize}

Days to $\mathbf{5 0 \%}$ anthesis: The main effect of variety showed highly significant $(\mathrm{P}<0.01)$ effect while intra- row spacing, and the interactions did not affect significantly days of $50 \%$ anthesis (Table 1). The longest days to $50 \%$ anthesis (82.00 days) was

Table 1: Descriptions of Maize Varieties used for study.

\begin{tabular}{|c|c|c|c|c|c|}
\hline Variety & Year of Release & Altitude (m) & Rain Fall (mm) & Days to Maturity & Seed Rate/ha kg \\
\hline BH546 & 2013 & $1000-1700$ & $1000-1200$ & 150 \\
\hline Shone(30G19) & 2008 & $1000-1200$ & $800-1200$ & 165 \\
\hline BHQPY-545 & 2008 & $1000-1700$ & $1000-1200$ & 145 \\
\hline
\end{tabular}

Varity Shone took the longest (86.58) days to reach $50 \%$ silking stage, while variety BHQPY-545 took shortest (83.08) days. There was significant difference among all varieties (Table 2). The significant difference among the varieties might be due to the variation in the genetic characteristics of the varieties. This finding is in line with Kahiu et al. [8] Who stated that there were difference in days to anthesis and days to silking among maize genotypes, while this finding disagree with Tokatlis \& Koutroubas [9] who reported that plant density affects the required interval for pollen shedding and silk emergence were takes long days as planting density of maize increased.

Table 2: Main effect of variety and intra-row spacing on days to anthesis and silking.

\begin{tabular}{|c|c|c|}
\hline Treatment & $\begin{array}{c}50 \% \text { Days of } \\
\text { Anthesis }\end{array}$ & $50 \%$ Days to Silking \\
\hline \multicolumn{3}{|l|}{ Maize Variety } \\
\hline Shone (30G19) & $82.00^{\mathrm{a}}$ & $86.58^{a}$ \\
\hline BH 546 & $79.83^{\mathrm{b}}$ & $84.42^{b}$ \\
\hline BHQPY-545 & $79.50^{b}$ & $83.08^{c}$ \\
\hline $\operatorname{LSD}(0.05)$ & 1.137 & 0.914 \\
\hline \multicolumn{3}{|l|}{$\begin{array}{c}\text { Intra row spacing } \\
(\mathrm{cm})\end{array}$} \\
\hline $20(66,667 \mathrm{PP})$ & 79.89 & 84.11 \\
\hline $25(53,333 \mathrm{PP})$ & 80.44 & 84.78 \\
\hline $30(44,444 \mathrm{PP})$ & 80.33 & 84.67 \\
\hline $35(38,093 \mathrm{PP})$ & 81.11 & 85.22 \\
\hline LSD (0.05) & NS & NS \\
\hline $\mathrm{CV}(\%)$ & 1.4 & 1.3 \\
\hline
\end{tabular}

LSD $(5 \%)=$ Least significance difference at $0.05 \%$ level CV=Coefficient of variation; NS=non-significant, $\mathrm{PP}=$ plants ha-1. Means in the same column within a parameter followed by the same letter(s) are not significantly different at $5 \%$ level of significance. recorded from variety Shone; while the shortest (79.50) was recorded under variety BHQPY-545 (Table 2). It might be due to the genetic variation between the varieties on maturity period. This finding is in line with Kahiu et al. [8] who stated that there was difference in days to anthesis and days to silking among maize genotypes.

Days to $\mathbf{5 0 \%}$ silking: The period of silking is a critical time for kernels formation after pollination. Any factor that affects silking and duration of silking can affect grain production directly. The main effect of variety showed highly significant $(\mathrm{P}<0.01)$ effect on $50 \%$ days to silking, while intra- row spacing, and the interactions did not significantly affect days to $50 \%$ silking (Table 1).

\section{Growth parameters of maize}

Leaf area: The analysis of variance showed highly significant $(p<0.01)$ difference in leaf area due to main effect of intra-row spacing. There was no significance difference due to variety and interaction (table 1). The highest leaf area $\left(6291 \mathrm{~cm}^{2}\right)$ was recorded from $35 \mathrm{~cm}$ intra-row spacing $(38,093$ plants ha-1) which was statistically at par with at $30 \mathrm{~cm}$ intra-row spacing, while the lowest $\left(5867 \mathrm{~cm}^{2}\right)$ was recorded from $20 \mathrm{~cm}$ intra-row spacing $\left(66,667\right.$ plants ha $\left.^{-1}\right)$ (Table 3 ). This might be due to that reduction of leaf area as a result of increasing plant density that led to the accelerated leaf senescence, increased shading of leaves, and reduced net assimilation of individual plants.

Table 3: Main effect of leaf area, LAI and Plant height on space and variety of green cob maize.

\begin{tabular}{|c|c|c|c|}
\hline Treatment & $\mathrm{LA}\left(\mathrm{cm}^{2}\right)$ & LAI & PH (cm) \\
\hline \multicolumn{4}{|c|}{ Maize Varieties } \\
\hline BH546 & 6171 & 3.168 & $255.0^{\mathrm{a}}$ \\
\hline BNQPY-545 & 6090 & 3.143 & $235.5^{\mathrm{b}}$ \\
\hline Shone(30G19) & 6085 & 3.113 & $263.3^{\mathrm{a}}$ \\
\hline LSD (0.05) & NS & NS & 14.643 \\
\hline \multicolumn{4}{|c|}{ Intra row spacing } \\
\hline $20(66,667 P P)$ & $5867^{b}$ & $3.975^{\mathrm{a}}$ & 257.8 \\
\hline 25 (53,333PP $)$ & $6018^{b}$ & $3.263^{\mathrm{b}}$ & 253.3 \\
\hline $30(44,444 \mathrm{PP})$ & $6285^{a}$ & $2.852^{\mathrm{c}}$ & 254 \\
\hline 35 (38,093PP) & $6291^{a}$ & $2.476^{\mathrm{d}}$ & 240 \\
\hline LSD (0.05) & 143.8 & 0.1 & N.S \\
\hline $\mathrm{CV}(\%)$ & 2.8 & 3.7 & 6.9 \\
\hline
\end{tabular}

$\mathrm{LA}=$ leaf area, $\mathrm{LAI}=$ leaf area index, $\mathrm{PH}=$ plant height. $\mathrm{LSD}(5 \%)=$ Least significance difference at $5 \%$ level, CV $(\%)=$ Coefficient of variation in percent; NS=non-significant. $\mathrm{PP}=$ the number in parentheses indicate plant ha- ${ }^{-1}$, Means column with in a parameter followed by the same letter(s) are not significantly different at $5 \%$ level of significance. 
This agrees with Sangakura et al. (2004) who reported that the leaf area per plant tended to decline with increasing plant density in maize. Similarly, Imran et al. [10] reported that lower plant population got more nutrients and water compared to higher population, thus contributed increased leaf area unlike high plant population density that reduced that reduced low leaf area of maize decreased.

Leaf area index: Leaf area index (LAI) showed highly significant $(\mathrm{P}<0.01)$ effect as affected by the main effect of intrarow spacing; but there was significant effect of variety and interaction (Table 1). The highest LAI (4) was recorded under $20 \mathrm{~cm}$ intra-row spacing with plant density of 66,667 plants $^{-1}{ }^{-1}$ and the lowest (3) was observed under $35 \mathrm{~cm}$ intra-row spacing with 38,093 plants ha-1. Leaf area index significantly decreased as plant density increased from 38,093 plants ha ${ }^{-1}(35 \mathrm{~cm}$ intrarow) to 66,667 plants ha-1 $(20 \mathrm{~cm}$ intra-row) (Table 3$)$.

In the current study, increase of LAI at narrowest row spacing $\left(66,667\right.$ plants ha $\left.^{-1}\right)$ and decrease with increasing intra-row indicates that LAI decrease as plant density increase. This study agrees with that of Valdabad and Farahani (2010) who reported that LAI is influenced by genotype, plant population, climatic condition and soil fertility. Saberali (2007) also indicated that in high maize density LAI increase more than at lower density throughout crop growing season.

However; this study agrees with that of Abuzar et al. [11] who reported that LAI of maize was significantly affected and increased in linear fashion with increase plant population. Other workers found results which disagree this finding. Imran et al. [10] reported maximum LAI from the lowest plant density and minimum LAI from the highest plant density. In this case, increase in number of plants per unit area beyond optimum level could probably reduce the amount of light availability to the individual plant, especially, to lower leaves due to shading. Generally, consistent increments in LAI were observed with increased plant population density. This dramatic increase in LAI with reduced intra row spacing or with increase in the plant population density might be due to occupation of more unit area by green canopy of the plants.

Plant heights: The analysis of variance showed statistically significant $(\mathrm{P}<0.05)$ different in plant height due to main effects of the variety; but there is no significance difference due to intrarow spacing and interaction effects (Table 1). This finding agrees with report of Raouf et al. [12] that had been significant plant height difference among maize cultivar.

Variety Shone was the tallest $(263.3 \mathrm{~cm})$, while variety BHQPY-545 was the shortest $(235.5 \mathrm{~cm})$ (Table 3$)$. This variation showed the existence of genetic difference among the varieties. In conformity with this result, Kunoskan [13] and Gozubenli et al. (2001) reported considerable varietal variation among plant height of maize cultivars. Narrow plant spacing is longer plant height 85.22 from $20 \mathrm{~cm}$ intera-row spacing; while the shortest
$(84.11 \mathrm{~cm})$ plant height from wide $35 \mathrm{~cm}$ intera-row spacing this is may be due to nutrients competition

\section{Yield component and yield}

Stand count (\%): The maize percent stand count was highly significantly $(\mathrm{P}<0.01)$ affected by the main effect of variety and intra-row spacing but the interaction effect was non-significant (Table 2). The highest (96.60\%) stand count was recorded from variety BH546 and the lowest (91.56\%) from variety BHQPY-545 (Table 4). This can be attributed to genetic difference of the varieties. Regarding the intra-row spacing the highest (97.92\%) stand count was recorded from $35 \mathrm{~cm}$ intra-row spacing, while the lowest (89.63\%) was recorded from $20 \mathrm{~cm}$ intra-row spacing (Table 4).

Table 4: Main effect of intra-row spacing and varieties on stand count (\%) and ear diameter of maize.

\begin{tabular}{|c|c|c|}
\hline Treatment & Stand Count (\%) & Ear Diameter $(\mathbf{c m})$ \\
\hline \multicolumn{3}{|c|}{ Maize Variety } \\
\hline BH 546 & $96.60^{\mathrm{a}}$ & $4.19^{\mathrm{a}}$ \\
\hline BHQPY-545 & $91.56^{\mathrm{b}}$ & $3.99^{\mathrm{b}}$ \\
\hline Shone (30G19) & $93.20^{\mathrm{b}}$ & $4.04^{b}$ \\
\hline LSD (0.05) & 2.16 & 0.1378 \\
\hline \multicolumn{3}{|c|}{ Intra Row-Row Spacing (cm) } \\
\hline $20(66,667 p p)$ & $89.63^{c}$ & $3.82^{\mathrm{c}}$ \\
\hline $25(53,333 p p)$ & $92.59^{b}$ & $4.02^{b}$ \\
\hline $30(44,444 p p)$ & $95.00^{\mathrm{b}}$ & $4.16 \mathrm{a}^{\mathrm{b}}$ \\
\hline 35 (38,093pp) & $97.92^{\mathrm{a}}$ & $4.29^{a}$ \\
\hline LSD $\mathrm{P}<0.05)$ & 2.5 & 0.1591 \\
\hline C.V (\%) & 2.7 & 4 \\
\hline
\end{tabular}

$\operatorname{LSD}(5 \%)=$ Least significance difference at $5 \%$ level CV (\%) $=$ Coefficient of variation; NS=non-significant at $5 \%$ level and SC= stand count in $\%, p p=$ the number in parentheses indicate plant ha- 1 , Means in the same column with in a parameter followed by the same letter(s) are not significantly different at $5 \%$ level of significance.

Stand count percent increase at wider intra-row spacing and decrease at narrow intra-row spacing. In general, plant stand percent decreased as plant population increased and this might be due to crowding effect. The other reason is that at lower population comparatively availability of more space might have resulted in less competition for resources (nutrients, moisture and light) whereas at high density competition resulted in weaker plants and mortalities by the time the crop approached maturity. This result agrees with; Eskandarnejada et al. [14] who reported higher plant stand count percent due to wider spacing combination of $75 \mathrm{~cm} \times 30 \mathrm{~cm}$ than narrow spacing of $55 \mathrm{~cm} \times$ $20 \mathrm{~cm}$. Similarly, Sangoi et al. [15] report that who wider inter and intra-row spacing of $75 \mathrm{~cm} \times 26.6 \mathrm{~cm}$ had greater plant stand count percent of maize compared to the initial count than that of narrow inter and intra-spacing of $5 \mathrm{~cm} \times 17.7 \mathrm{~cm}$.

Ear diameter: The main effect of intra-row spacing showed highly significant $(\mathrm{P}<0.01)$ effect on maize diameter while that of 
variety was significant $(\mathrm{P}<0.05)$ effect on ear diameter. However, the interaction effect was not significant (Table 3). The highest ear diameter $(4.19 \mathrm{~cm})$ was record from variety BH546, while the lowest (3.99) was produced by variety BHQPY-545. The ear diameter of variety BHQPY-545 and shone were not significantly different (Table 4). This might be due to genetic variation among the varieties. The highest $(4.29 \mathrm{~cm})$ and the lowest $(3.82 \mathrm{~cm})$ ear diameter were recorded at intra-row spacing of $35 \mathrm{~cm}$ and $20 \mathrm{~cm}$ respectively (Table 4).

There was statistically significant difference among 20, 25, and $35 \mathrm{~cm}$ and no significance difference between 30 and $25 \mathrm{~cm}$ intra-row spacing. Ear diameter increase as intra-row increased. This might be because of comparatively less computation for resources like moisture, nutrient, and light in low in this plant population density.

Number of ears per plant: The analysis of variance showed highly significant $(\mathrm{P}<0.01)$ effect of intra-row spacing, variety and the interaction on number of ears per plant (Table 2). The highest (1.75) number of ear plant-1 was scoured from the interaction of the variety BH546 and BHQPY-545 with $35 \mathrm{~cm}$ intra- row spacing produced.

This showed that variety BH546 and BHQPY-545 performed better at $35 \mathrm{~cm}$ intra-row spacing in bearing ears per plant than at other spacing and variety Shone. The lowest (1.00) ear per plant was recorded from the variety Shone and BH 546 with $20 \mathrm{~cm}$ intra- row spacing. In general number of ears per plant increased in all varieties as intra-row increased (Table 5).

Table 5: Interaction effect of varieties and intera-row spacing on number of ears per plant.

\begin{tabular}{|c|c|c|c|c|}
\hline \multirow{2}{*}{$\begin{array}{c}\text { Maize } \\
\text { Varieties }\end{array}$} & \multicolumn{4}{|c|}{ Intra-Row Spacing (cm) } \\
\cline { 2 - 5 } & $\mathbf{2 0}$ & $\mathbf{2 5}$ & $\mathbf{3 0}$ & $\mathbf{3 5}$ \\
\hline BH 546 & $1.01^{\mathrm{f}}$ & $1.53^{\mathrm{bc}}$ & $1.55^{\mathrm{b}}$ & $1.75^{\mathrm{a}}$ \\
\hline BHQPY-545 & $1.03^{\mathrm{f}}$ & $1.43^{\mathrm{cd}}$ & $1.63^{\mathrm{b}}$ & $1.75^{\mathrm{a}}$ \\
\hline hone(30G19) & $1.00^{\mathrm{f}}$ & $1.23^{\mathrm{e}}$ & $1.37^{\mathrm{d}}$ & $1.39^{\mathrm{d}}$ \\
\hline LSD (0.05) & 0.1156 & & & \\
\hline CV (\%) & 4.9 & & & \\
\hline
\end{tabular}

LSD = least significant difference, $N S=$ non significance $C V=$ coefficient of variation in percent. Means column within a parameter followed by the same letter(s) are not significantly different at $5 \%$ level of significance.

This study agrees with Zamir et al. [16] who report that as plant density in unit area increased the numbers of ears per plants become decrease due to competition among the plants. Also, in line with this result, Hashemi-Dezifouli and Herbert (1992) reported significantly higher number of cobs plant-1 at lower plant density compared to higher plant density. Variety (Shone) the lowest ears per plant than the other two varieties at all intra row spacing, except at $20 \mathrm{~cm}$ produced. In this currently study generally number of ears per plant increase in all varieties as intera-row spacing increased.
Ear length: The analysis of variance showed that ear length was highly significantly $(\mathrm{P}<0.01)$ affected by the main effect of intra-row spacing, variety and their interaction (Table 3).

The significantly longest ear $(35.00 \mathrm{~cm})$ was recorded from BH546 treated under $35 \mathrm{~cm}$ intra-rows spacing at plant density 38,095 plants ha ${ }^{-1}$. The shortest ear length $(23 \mathrm{~cm})$ was obtained from Shone grown at intra-row spacing $20 \mathrm{~cm}(66,667$ plants ha $^{-1}$ ). In general ear length decreased with decreased intra-row spacing (increased plant density) (Table 6). The longer ear at lower plant population (increased intra-row spacing) might be because at lower population level there are available space and less competition for resources in low plant population density.

Table 6: Interaction of varieties and intera-row spacing on ear length at harvest of green cob maize.

\begin{tabular}{|c|c|c|c|c|}
\hline \multirow{2}{*}{ Maize Variety } & \multicolumn{4}{|c|}{ Intra-Row Spacing } \\
\cline { 2 - 5 } & $\mathbf{2 0} \mathbf{c m}$ & $\mathbf{2 5} \mathbf{c m}$ & $\mathbf{3 0} \mathbf{c m}$ & $\mathbf{3 5} \mathbf{c m}$ \\
\hline BH546 & $27.33^{\mathrm{gh}}$ & $29.75^{\mathrm{e}}$ & $31.00^{\mathrm{cd}}$ & $35.00^{\mathrm{a}}$ \\
\hline BHQPY-545 & $25.28^{\mathrm{i}}$ & $28.17^{\mathrm{fg}}$ & $28.47^{\mathrm{f}}$ & $31.67^{\mathrm{bc}}$ \\
\hline Shone(30G19) & $23.00^{\mathrm{j}}$ & $26.33^{\mathrm{gh}}$ & $30.08^{\mathrm{cd}}$ & $32.33^{\mathrm{b}}$ \\
\hline LSD (0.05) & 1.039 & & & \\
\hline CV (\%) & 2.1 & & & \\
\hline
\end{tabular}

LSD =least significant difference, $\mathrm{CV}(\%)=$ coefficient of variation in present, $\mathrm{pp}=$ the number in the parentheses indicate plant ha ${ }^{-1}$, Means column within a parameter followed by the same letter(s) are not significantly different at $5 \%$ level of significance.

Regarding the longest ear $(35 \mathrm{~cm})$ of maize was observed from variety BH546 treated fewer than $35 \mathrm{~cm}$ intra-rows spacing; while the variety BHQPY-545 produced shortest ear length $(31.67 \mathrm{~cm})$ at the same intra-row spacing might be due to genetic variation among these varieties. This result is in line with the finding of Abuzar et al. [11], who reported significant differences among the varieties of maize for ear length. Similarly, Lakew et al. [17] where they reported significant differences among the varieties of maize in ear length and ear diameter.

Adeniyan [18] also observed decreased maize ear length under increased population densities and attributed that the plant population above and below critical density has a negative effect on yield per plant because of inter plant competition for light, water, nutrient and other potential yield-limiting environmental factors. Reduction of ear length and diameter with narrower row spacing is attributed to limitation of assimilates as a result of low photosynthetic processes of leaves at narrow row spacing due to less availability of growth influencing factors and genetic variation among the varieties, which resulted in high or low ear length and diameter.

Number of ears per hectare: The main effect of intra-row spacing showed highly significant $(\mathrm{P}<0.01)$ effect on ear per hectare and variety showed significant $(\mathrm{p}<0.05)$ effect. But the interaction effect was nonsignificant effect (Table 3). 
The highest $(57,962)$ number of ears per hectare was obtained from variety BH546, while the lowest $\left(52,037 \mathrm{ha}^{-1}\right)$ was from variety Shone. Variety BHQPY 545 was at par with BH546 and Shone varieties. Variety BH546 gave more ear ha-1 than the other two varieties, indicating that this variety is preferable than other in terms of cob number (Table 7). The highest number of ear $\left(62,222 \mathrm{ha}^{-1}\right)$ was recorded from $25 \mathrm{~cm}$ intra-row spacing at plant population $\left(53,333 \mathrm{ha}^{-1}\right)$ which was statistically at par with $\left(57,530 \mathrm{ha}^{-1}\right)$ from $20 \mathrm{~cm}$ intra-row spacing $\left(66,667\right.$ plants ha $\left.{ }^{-1}\right)$. There was no significant difference between $20 \mathrm{~cm}$ and $25 \mathrm{~cm}$ intra row spacing, indicating that one of the two could be used for green cob production; while $25 \mathrm{~cm}$ intra-row spacing is the best one. The lowest $(47,654)$ number of ears per hectare was recorded from $35 \mathrm{~cm}$ intra-row spacing.

Table 7: Maine effect of varieties and intra-row space ears per hectare on green cob maize.

\begin{tabular}{|c|c|}
\hline Treatment & Ear/ha \\
\hline \multicolumn{2}{|c|}{ Maize Variety } \\
\hline BH 546 & $57,962^{\mathrm{a}}$ \\
\hline BHQPY-545 & $55,000^{\mathrm{ab}}$ \\
\hline Shone (30G19) & $52,037^{\mathrm{b}}$ \\
\hline \multicolumn{2}{|c|}{ Intra-Row Spacing (Cm) } \\
\hline $20(66,667 P$ P) & 4267.2 \\
\hline $25(53,333 P$ P) & $57,530^{\mathrm{a}}$ \\
\hline $30(44,444 P P)$ & $62,222^{\mathrm{a}}$ \\
\hline $35(38,093 P P)$ & $52,592^{\mathrm{b}}$ \\
\hline LSD (0.05) & $47,654^{\mathrm{c}}$ \\
\hline CV (\%) & 4927.3 \\
\hline
\end{tabular}

LSD = least significant difference, $\mathrm{CV}(\%)=$ coefficient of variation in percent, $\mathrm{PP}=$ the number in the parentheses indicate plants ha-1, Means column with in a parameter followed by the same letter(s) are not significantly different at $5 \%$ level of significance.

This finding agrees with [19] who reported that grain yield increased with increasing plant density linearly until production factors are not limiting. Also, it is in line with Sabo et al. [20] who report that intra-row spacing $25 \mathrm{~cm}$ resulted in the highest (23.11) cob per plot $30 \mathrm{~cm}$ followed (21.56); while $20 \mathrm{~cm}$ resulted the least (17.78) cob per plot. In this current study the reason $25 \mathrm{~cm}$ intra-row spacing record high cob yield ha-1 was the plant population is greater than that of 30 and $35 \mathrm{~cm}$ intra-row spacing; while $20 \mathrm{~cm}$ intra-row spacing may affected by limitation factor than the other [21-26].

\section{Summary and Conclusion}

Among agronomic practices, variety and plant spacing require special attention. Therefore, the present experiment was conducted in 2017/18 irrigation cropping season at the study area, with the objectives of assessing the effects of maize variety and intra-row spacing on growth, yield and yield components, and on green cob yield of maize. The treatment consisted of factorial combination of 4 intra-row spacing (20, 25,30 and $35 \mathrm{~cm}$ ) and three varieties of maize (BH546, Shone, and BHQPY-545). The recommended inter row spacing of $75 \mathrm{~cm}$ for maize was used uniformly. The experiments were laid out in randomized complete block design (RCBD) in $4 \times 3$ factorial arrangements with three replications.

The main effect of variety was highly significant $(\mathrm{P}<0.01)$ on days to $50 \%$ anthesis, days of $50 \%$ silking, plant height, ear diameter, and ears per hector; whereas intra-spacing and interaction were not significant. The variety Shone took maximum (82) days to reach $50 \%$ anthesis; while the variety BHQPY-545 took minimum (79.50) days to reach 50\% anthesis. Variety shone took the longest (86.56) days to reach $50 \%$ of silking; while variety BHQPY-545 was the earliest (83.08) to reach days to $50 \%$ silking stage.

Intra-row spacing had highly significant $(\mathrm{P}<0.01)$ effect on plant leaf area and leaf area index. The highest leaf area $\left(6291 \mathrm{~cm}^{2}\right)$ was recorded from $35 \mathrm{~cm}$ intra-raw spacing, which was statistically at par with $30 \mathrm{~cm}$ intra-row spacing $\left(6285 \mathrm{~cm}^{2}\right)$. Leaf area index showed an increasing trend with decreasing intra-row spacing. The highest (3.975) leaf area index recorded was from $20 \mathrm{~cm}$ intra-row spacing, while the minimum (2.476) leaf area index recorded was from $35 \mathrm{~cm}$ intra-row spacing. Variety Shone (30G19) had the tallest plant height $(263.3 \mathrm{~cm})$, while the variety BHQPY-545 was shortest $(235.5 \mathrm{~cm})$.

BH546 gave the highest ear diameter $(4.19 \mathrm{~cm})$, while variety BHQPY-545 gave the narrowest ear diameter $(3.99 \mathrm{~cm})$. Regarding the main effect of intra-row spacing, the largest diameter $(4.29 \mathrm{~m})$ was obtained from $35 \mathrm{~cm}$ intra-row with plant population density of 38,095 plants $\mathrm{ha}^{-1}$, while the smallest $(3.82 \mathrm{~cm})$ ear diameter was recorded from $20 \mathrm{~cm}$ intrarow spacing. The highest number of ears per hectare $(57,962)$ was obtained from variety BH546, while the lowest number of ears $(52,037)$ ha $^{-1}$ was recorded from variety Shone. Intra-row spacing also has significant different ear ha-1; the highest ears ha $^{-1}$ recorded from $20 \mathrm{~cm}$ and $25 \mathrm{~cm}$ at par with $(57,530)$ and $(62,222)$; while the lowest ears $\mathrm{ha}^{-1}$ was recorded at $3 \mathrm{~cm}$ intrarow spacing.

Variety with intra-row spacing had highly significant effect on the number of ears per plant and ear length. The highest (1.75) number of ear plant-1 was obtained from BH546 at 35 $\mathrm{cm}$ intra- row spacing, whereas, the lowest (1.00) number of ears per plants was form Shone at $20 \mathrm{~cm}$ intra-row spacing. This result showed that the varieties BH546 and BHQPY-545 at $35 \mathrm{~cm}$ intra-row spacing were better in bearing ears per plant, having an average of 1.75 ears per plant.

The highest ear length $(35 \mathrm{~cm})$ was recorded from BH546 with intra-row spacing of $35 \mathrm{~cm}$, while the shortest ear lengths $(23 \mathrm{~cm})$ was obtained from Shone (30G19) at intra-row spacing $20 \mathrm{~cm}$. Generally, long ears were observed at lower plant populations, which might be due to less competition, thus more 
available space and resources for individual plants to produce long ears at low plant density.

Finally, the result of present study showed that variety and intra-row spacing had significant influences on most of the phonological parameters, yield and yield components of maize. The result also indicated that variety BH546 was the most suitable of the three maize varieties tested, and $25 \mathrm{~cm}$ intra-row spacing was better to achieve optimum yield. However, this is a one season experiment at one location, thus the experiment must be repeated over locations and seasons to reach at a better reliable conclusion.

\section{References}

1. Davis CM, Reddy BR, Reddy PM, Reddy SCS (1995) Effects on Nitrogen levels and plant density on yield and quality of JKHY-1 cotton. Current Agricultural Research 8(4): 144-146.

2. Malik VS, Swanton CJ, Mikaels TE (1993) Interaction of white bean (Phaseolus vulgaris) cultivars, row spacing and seeding density with annual weeds. Weed Science 41(1): 62-68.

3. Murphy SD, Yakubu Y, Weise SF, Swanton CJ (1996) Effects of planting pattern and inter row cultivation on competition between corn (Zea mays L.) and late emerging weeds. Weed Science 44(4): 865-870.

4. Andrade FH, Calvino P, Cirilo A, Barbieri P (2002) Yield response to narrow rows depends on increased radiation interception. Agronomy Journal 94(5): 975-980.

5. Chinyere P (2013) Plant Spacing, Dry Matter Accumulation and Yield of Local and Improved Maize Cultivars. International Journal of Agriculture and Environmental (01): 1526.

6. Mupangwa M, Wegary D (2018) Closing the gap between the potential yield and obtained results of improved maize varieties: Case for Ethiopia. African Seed Association (AFSTA) Congress, at Cairo, Egypt (CIMMYT).

7. Adimasu M (2014) Hybrid maize seed production manual. Ethiopia Seed Association. Addis Ababa, Ethiopia.

8. Ngugi K, Cheserek J, Muchira C, Chemining'wa G (2013) Anthesis to Silking Interval Usefulness in Developing Drought Tolerant Maize. Dept of Plant Sciences and Crop Protection, Faculty of Agriculture, College of Agriculture and Veterinary Sciences, University of Nairobi, Nairobi, Kenya.

9. Tokatlis IS, Koutroubas SD (2004) A review of maize hybrids dependence on high plant populations and its implications for crop yield stability. Field Crops Research 88(2/3): 103-114.

10. Imran S, Arif M, Khan A, Khan MA, Shah W, et al. (2015) Effect of nitrogen levels and plant population on yield and yield components of maize. Advances in Crop Science and Technology 56: 1-7.

11. Abuzar MR, Sodazai GU, Bolach MS, Bolach AA, Shah IH, et al. (2011) Effect of Plant Population Densities on Yield of Maize. The journal of Animal and Plant Sciences 21(4): 692-695.
12. Raouf SS, Sedghi M, Gholipouri A (2009) Effect of Population Density on Yield and Yield attribute of maize hybrids. Research journal of Biology sciences 4(4): 375-379.

13. Kunoskan O (2000) Effect of plant density on yield and yield related characters on of some maize hybrids grown in hatey condition as second crop. M.SC. Thesis, Science Institute. M.K.U. 8(3): 71-75.

14. Eskandarnejada S, Khorasani S, Bakhtiaric A, Heidarian R (2013) Effect of row spacing and plant density on yield and yield components of sweet corn (Zea mays L.). Journal of Crop Science 13(1): 81-88.

15. Sangoi L, Ender M, Guidolin A, de Almeida ML, Heberle PC (2001) Influence of row spacing reduction on maize grain yield and yield components. Agronomy Journal 36(6): 861-869.

16. Zamir MSI, Ahmad AH, Javeed HMR, Latif T (2011) Growth and yield behavior of two maize hybrids (zea mays L.) towards different plant spacing. Cercetări Agronomiceîn Moldova 44(2): 33-40.

17. Getaneh L, Belete K, Tana T (2016) Growth and Productivity of Maize (Zea mays L.) as Influenced by Inter and Intra-Row Spacing in Kombolcha, Eastern Ethiopia. MSc, Thesis, Haramaya University, Haramaya, Ethiopia. Journal of Biology, Agriculture and Healthcare 6(13): 1-12.

18. Adeniyan ON, Ojeniyi SO (2005) Effect of poultry manure, NPK 1515-15 fertilizer and combination on of their reduced levels on maize growth and soil chemical properties. Nigerian J Soil Sci 15: 34-41.

19. Anjum JJ, Ali EH, Sahi CN, Khan ZH (1992) Effect of fertilizer on growth and yield of summer maize. International Journal of Agriculture Research 30(4): 453-457.

20. Sabo MU, Wailare MA, Aliyu MJ, Sanusi MH (2016) Effect of variety and spacing on growth and yield of maize (Zea mays L.) in Bauchi State, Nigeria. Int Plant and Soil Sci 9(6): 1-6.

21. Ali SK, Khalil SM, Raza H, Khan R (2003) Effect of herbicides and row spacing on maize. Pak Journal of Weed Science Research 9(3-4): 171178.

22. ATA (Agricultural Transformation Agency) (2013) Maize Production Manual for Extension Staff in Ethiopia of Ministry of Agriculture, ATA. Addis Ababa, Ethiopia.

23. EARO (Ethiopian Agricultural Research Organization) (2004) Directory of released crop varieties and their recommended cultural practices. Addis Ababa, Ethiopia.

24. Khan AB (1972) The effect of different plant population, nitrogen doses and number of irrigations on the yield and other agronomic characters of maize. M.Sc. Thesis. Department of Agronomy, Faculty of Agriculture, University of Peshawar, Pakistan.

25. Malik AL, Singh HG (1989) Effect of supplemental light and regulation of leaf nutritional environment on productivity of maize at various intra-row spacing. Madras Agricultural journals 76(1): 5-9.

26. Porter PM, Hicks DR, Lueschen WE, Ford JH, Warnes DD, et al. (1997) Corn response to row width and plant density in the northern Corn Belt. Journal of Production Agriculture 10(2): 293-300. 
Your next submission with Juniper Publishers will reach you the below assets

- Quality Editorial service

- Swift Peer Review

- Reprints availability

- E-prints Service

- Manuscript Podcast for convenient understanding

- Global attainment for your research

- Manuscript accessibility in different formats ( Pdf, E-pub, Full Text, Audio)

- Unceasing customer service

Track the below URL for one-step submission https://juniperpublishers.com/online-submission.php 